\title{
Record of the rare Caribbean mud eel, Pythonichthys sanguineus (Heterenchelyidae, Anguilliformes), in the region of the Amazon Reef
}

Matheus Marcos ROTUNDO ${ }^{1}$, Leonardo MACHADO $^{2}$, Claudio OLIVEIRA ${ }^{2}$, Wagner César Rosa dos SANTOS 3 , Alexandre Pires MARCENIUK ${ }^{2,3, *}$

Universidade Santa Cecília, Acervo Zoológico, Santos, SP, Brasil.

2 Universidade Estadual Paulista, Departamento de Morfologia, Botucatu, SP, Brasil.

Centro de Pesquisa e Gestão de Recursos Pesqueiros do Litoral Norte (CEPNOR), Belém, Pará, Brasil.

* Corresponding author: a_marceniuk@hotmail.com

\section{ABSTRACT}

As they spend most of their time buried in the substrate and are not a fishery resource, heterenchelyids are seldom seen. These eels are characterized by their greatly reduced eyes, which are covered by semi-transparent skin, the absence of a pectoral fin or lateral line, and no pores on the head or body. Pythonichthys sanguineus is a particularly poorly-known species, with only eight scientific records from Cuba, Puerto Rico, Colombia, Venezuela, Guyana, and Suriname. The present study is based on six adult specimens of $P$. sanguineus captured by vessels of the shrimp trawling fleet along the northern Brazilian coast, in the vicinity of the Amazon Reef. We provide meristic, morphometric and DNA barcoding data. These findings provide insights into the distribution of the species off the northern Brazilian coast and contribute to the discussion about the southern limit of the Greater Caribbean fauna.

KEYWORDS: fisheries, conservation, Brazilian northern coast, new record, systematics

\section{Registro da rara enguia de lama do Caribe, Pythonichthys sanguineus (Heterenchelyidae, Anguilliformes) na região dos Recifes da Amazônia}

\section{RESUMO}

Heterenchelídeos passam a maior parte do tempo enterrados no substrato e raramente são vistos, não representando recursos pesqueiros importantes. Essas enguias sáo caracterizadas por seus olhos muito reduzidos e cobertos por pele semi-transparente, ausência de nadadeiras peitorais ou linha lateral, e ausência de poros na cabeça ou no corpo. Pythonichthys sanguineus é uma espécie particularmente pouco conhecida, com apenas oito registros em coleçáo zoológica para Cuba, Porto Rico, Colômbia, Venezuela, Guiana e Suriname. O presente estudo é baseado em seis espécimes adultos de P. sanguineus capturados pela frota industrial de arrasto de camarão-rosa na costa norte do Brasil, ao largo dos Recifes da Amazônia. Apresentamos dados merísticos, morfométricos e de DNA barcoding dos exemplares examinados. O registro fornece informaçóes importantes sobre a distribuiçáo da espécie na costa norte do Brasil, e contribui para a discussão sobre o limite sul da fauna do Grande Caribe.

PALAVRAS-CHAVE: pesca, conservação, costa norte do Brasil, novo registro, sistemática

\section{INTRODUCTION}

The order Anguilliformes includes 938 species in 19 families and 159 genera (Nelson et al. 2016). The marine mud eels of the family Heterenchelyidae, a sister group to the Myrocongridae and Muraenidae (Inoue et al. 2010), are a small group of two genera, Panturichthys Pellegrin 1913 and Pythonichthys Poey 1868, found in the Mediterranean, tropical Atlantic, and eastern Pacific (Nelson et al. 2016). As they spend most of their time buried in the substrate, heterenchelyids are seldom seen, not representing a fishery resource (Smith 2015). These eels, which can reach a total length of $1 \mathrm{~m}$, are characterized by their greatly reduced eyes, which are covered by semi-transparent skin, the absence of a pectoral fin or lateral line and no pores on the head or body (Smith 1989).

At least four species of Pythonichthys are known to exist. Pythonichthys microphthalmus (Regan 1912) and Pythonichthys macrurus (Regan 1912) are found in the Eastern Atlantic (EA), while Pythonichthys asodes Rosenblatt \& Rubinoff 1972 occurs in the Eastern Pacific (EP), and Pythonichthys sanguineus Poey 1868 is the only species found in the Western 
Atlantic (WA) (Figure 1a). Smith (1989) described the history and diversity of the heterenchelyids and redescribed the osteology of $P$. asodes and $P$. macrurus. Eagderi and Adriaens (2010) also described the osteology of these species, Blache (1977) described the leptocephalus larvae from the Gulf of Guinea. Pythonichthys sanguineus, a senior synonym of Heterenchelys biaggii Böhlke (1956) (sensu Smith 1989; Smith et al. 2012) is the least well known species of the genus, and nothing is known of its biology (Smith 1989, 2002; Smith et al. 2012). Only eight records of adult specimens of $P$. sanguineus are found in zoological collections (in 10 collection lots), representing six different localities. Two specimens are known from Cuba (MCZ 32805 and USNM 111340) and three from Puerto Rico, including the type specimens of Heterenchelys biaggii (FMNH 61775, ANSP 73872 and FMNH 61774). From South America, five specimens are available from Venezuela (four specimens, MBUCV 293 and one specimen from the Fernandez Yepez's collection), and one each from Colombia (UMML 222150), Guyana (BMNH 1961.8.31.99) and Suriname (NSMT 40060), while the 11 specimens examined by Poey (1868) have been lost (Faloh-Gandarilla et al. 2016).

Considering the general lack of data on the fish diversity of the northern coast of Brazil (Marceniuk et al. 2013; Marceniuk et al. 2017), the Centro de Pesquisa e Gestão de Recursos Pesqueiros do Litoral Norte (CEPNOR), together with
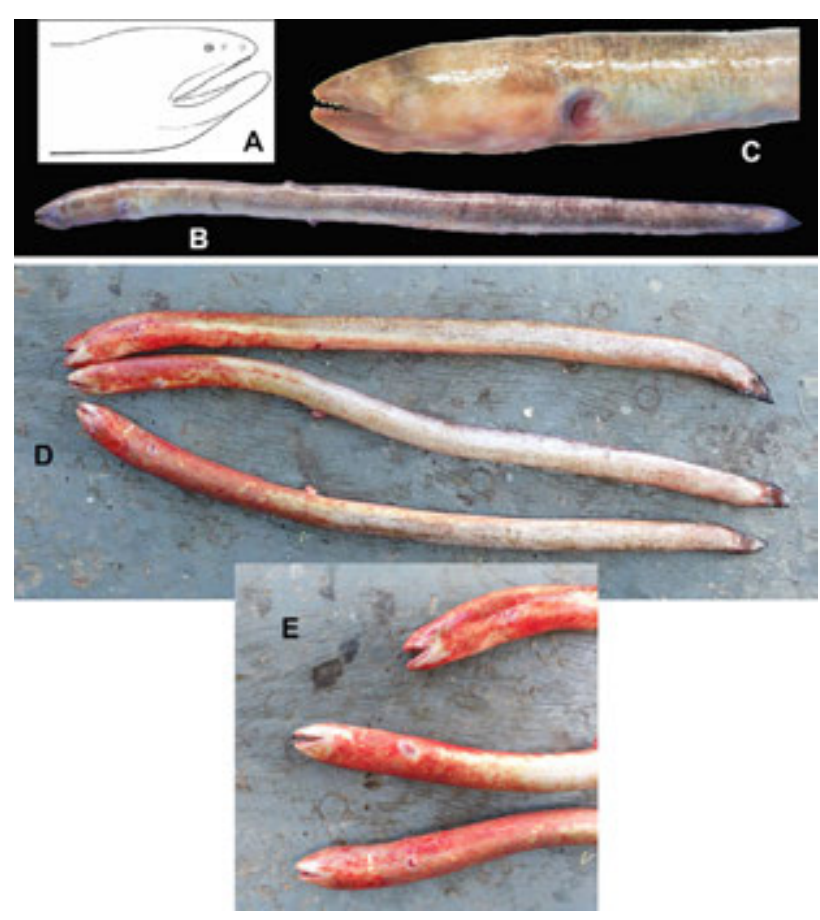

Figure 1. Pythonichthys sanguineus, body and head in lateral view. A. Holotype drawn by Poey (1868); B-C. Cataloged Brazilian specimen (MPEG 35269); D-E. Non-cataloged Brazilian specimen. This figure is in color in the eletronic version. taxonomists from the Museu Paraense Emílio Goeldi (MPEG), in Belém, Brazil, has obtained specimens from the industrial shrimp otter trawling fleet based in the Brazilian state of Pará, in a concentrated effort to expand the scientific inventory of the marine fish diversity of the region. This sampling effort has resulted in the collection of six specimens of P. sanguineus. Meristic, morphometric and DNA barcoding data are presented (cataloged specimens), and provide important insights into the distribution and diversity of the genus in the western Atlantic.

\section{MATERIAL AND METHODS}

The present report on Pythonichthys sanguineus is based on three adult specimens collected in Amapá state on April 28, 2017 and March 2-3, 2018 (cataloged, Figure1b,c) and other three adult specimens captured on March 5, 2018 (not cataloged, Figure 1d,e), all captured by vessels of the shrimp trawling fleet. The cataloged specimens were deposited in the zoological collections of Museu Paraense Emílio Goeldi (MPEG 35269, 493 mm TL (total length), 2¹9'42”N, 48³6'46”W, 50 m), Acervo Zoológico da Universidade Santa Cecília (AZUSC $5314,650 \mathrm{~mm}$ TL, 2 $19^{\prime} 39^{\prime} \mathrm{N}, 48^{\circ} 2635^{\prime} \mathrm{W}, 50 \mathrm{~m}$ ), and the fish collection of Laboratório de Biologia e Genética de Peixes of Universidade Estadual Paulista Júlio de Mesquita Filho (LBP 26612, $431 \mathrm{~mm}$ TL, 152’45”N, 48¹6’32”W, $44 \mathrm{~m}$ ) (see Material Examined). The specimens were identified based on the original description and subsequent references (Smith 1989, 2002, Smith et al. 2012), and measured according to Smith (1989). All measurements were taken using either a digital calliper (precision $0.01 \mathrm{~mm}$ ) or a ruler (precision $1 \mathrm{~mm}$ ) for dimensions over $200 \mathrm{~mm}$. The data on the occurrence of $P$. sanguineus were obtained from the zoological collection records available at http://www.fishnet2.net and in Smith (1989).

\section{Molecular analysis}

Molecular identification of the specimens was done according to the DNA barcoding protocol (Hebert et al. 2003) and deposited in the BOLD system (Ratnasingham and Hebert 2007) and in Genbank (https://www.ncbi.nlm.nih.gov/ genbank). A partial COI sequence (578 bps) was obtained from a single $P$. sanguineus specimen deposited at Museu Paraense Emílio Goeldi (MPEG 35269), and deposited in the Genbank database (accession number: MG833002) and BOLD (RMRBR001-18). For comparison, COI sequences of additional 57 anguilliforms were obtained from NCBI (see Supplementary Material, Appendix S1). These sequences were derived from a phylogenetic study that analyzed the mitochondrial genomes of all 19 anguilliform families (Inoue et al. 2010) and represent an almost complete sample of Anguilliformes at genus level.

The molecular assays were conducted at the Laboratory of Fish Biology and Genetics at Universidade Estadual Paulista Júlio de Mesquita Filho in Botucatu, São Paulo, Brazil. Total genomic DNA was isolated from muscular 
tissue using an automated glass fiber protocol (Ivanova et al. 2008). The fragment at the 5' end of the mitochondrial COI gene was amplified by PCR using the primers FishF1 and FishR1 (Ward et al. 2005). The reactions were carried out in a $12.5 \mu \mathrm{L}$ reaction volume containing $1.25 \mu \mathrm{L}$ of $10 \times$ PCR buffer, $0.375 \mu \mathrm{L} \mathrm{MgCl} 2(50 \mathrm{mM}), 0.5 \mu \mathrm{L}$ of the dNTPs (2 $\mathrm{mM}), 0.25 \mu \mathrm{L}$ of each primer $(5 \mu \mathrm{M}), 0.2 \mu \mathrm{L}$ of $1.25 \mathrm{U}$ Taq platinum DNA polymerase, and $1 \mu \mathrm{L}$ of the DNA template (200 ng), and $8.675 \mu \mathrm{L}$ of ultrapure water. The PCR cycle was as follows: $95^{\circ} \mathrm{C}$ for $3 \mathrm{~min}$, followed by 35 cycles of $95^{\circ} \mathrm{C}$ for $30 \mathrm{~s}, 54^{\circ} \mathrm{C}$ for $45 \mathrm{~s}, 72^{\circ} \mathrm{C}$ for $1 \mathrm{~min}$, and then $72^{\circ} \mathrm{C}$ for $5 \mathrm{~min}$. The PCR products were visualized in a $1 \%$ agarose gel and purified using ExoSAP-IT (USB Europe GmbH, Staufen, Germany) at $37^{\circ} \mathrm{C}$ for $60 \mathrm{~min}$ followed by $15 \mathrm{~min}$ at $80^{\circ} \mathrm{C}$. The sequencing reactions were conducted using a BigDye Terminator Cycle Sequencing kit (Applied Biosystems, California, USA) according to the manufacturer's instructions. The sequences were read in both the forward and reverse directions, and the primers used for sequencing were the same as those used for the PCR reaction. Finally, the labeled sequences were assessed using an ABI PRISM 3130 Genetic Analyzer (Applied Biosystems, California, USA).

Bidirectional sequences were assembled using Geneious v.5.6 (Kearse et al. 2012) to obtain consensus sequences and to check for indels or stop codons. Indels or stop codons, which may indicate the amplification of nuclear mithocondrial DNA segment (NUMTs), were absent from all sequences. Genetic distances between and within taxonomic groups were calculated using the Kimura 2-parameter (K2P) substitution model (Kimura 1980) in MEGA 7 (Kumar et al. 2016). The best model of nucleotide substitution was GTR+G+I as calculated in MEGA 7 (Kumar et al. 2016). The maximum likelihood tree was obtained in MEGA 7 (Kumar et al. 2016) using the GTR+G+I model, with node supports estimated by 1000 nonparametric bootstrap replicates (Felsenstein 1985).

\section{RESULTS}

Pythonichthys sanguineus Poey 1868

Pythonichthys sanguineus Poey 1868: 265 (original description); Uyeno and Sasaki in Uyeno et al. 1983:101 (Suriname); Smith 1989:52 (taxonomic considerations); Cervigón 1991:29 (Venezuela); Aguilera 1998:46 (Venezuela); Smith 2002:694 (Western Central Atlantic); Smith et al. 2012:492 (Caribbean); Faloh-Gandarilla et al. 2016:28 (Cuba).

Heterenchelys biaggii Böhlke 1956:8, Fig. 2A (original description, Puerto Rico).

\section{Diagnosis}

Some authors have expressed doubts about the distinction between the genera Pythonichthys and Panturichthys (Rosenblatt and Rubinoff 1972). The identification of the specimens analyzed here as Pythonichthys was supported by the diagnostic characters proposed by Blache (1968): the absence of a longitudinal cutaneous ridge on the upper surface of the head (vs. present in Panturichthys), the absence of the fleshy fold located posteriorly on the inner edge of the maxilla ( $v s$. present in Panturichthys), the presence of a gap between the vomerine and ethmoid dentition ( $v$ s. absent in Panturichthys), the inner row of maxillary teeth is approximately equal in length to the outer row ( $v$ s. shorter in Panturichthys), the pectoral girdle originates dorsally ( $v s$. on or slightly anterior to the pectoral waist in Panturichthys), head and trunk 22-36\% TL (vs. 12-20\% TL in Panturichthys, Table 1), and 109-134 vertebrae (vs. 141-227 in Panturichthys, Table 1).

While counts of vertebrae and proportional measurements can be used to distinguish $P$. sanguineus from $P$. macrurus (EA) and $P$. asodes (EP), these parameters are highly similar to those observed in P. microphthalmus (EA). Pythonichthys sanguineus can nevertheless be distinguished from P. microphthalmus by the number of vomerine tooth rows (2-3), in contrast with a single row in $P$. microphthalmus, and 3-5 maxillary and mandibular tooth rows ( $v$ s. 2 rows in P. microphthalmus). The two species are also differentiated clearly by the molecular data (see below).

\section{Molecular analysis}

Maximum likelihood analysis showed that the specimen analyzed here clusters with Pythonichthys microphthalmus, with a bootstrap support of $60 \%$ (Figure 2), corroborating the assignment of our specimens to the genus Pythonichthys. The K2P genetic distance between $P$. sanguineus and $P$. microphthalmus was $25.0 \pm 1.9 \%$, with $89 / 578$ positions being different between species, corroborating our hypotheses that these are in fact different species.

\section{Morphological measurements}

The morphometric and meristic parameters of the specimens analyzed in here did not exceed the amplitude of values presented in the original description or subsequent studies (Table 1).

\section{Color Pattern}

Scharpf and Lazara (2017) refer to the coloration of fresh Pythonichthys sanguineus as blood-red. The living specimens (Figure 1d,e) presented the same coloration described by Scharpf and Lazara (2017), while the fresh specimen was light gray, with a brownish anterior dorsal region extending to approximately the anus, and a pale belly (Figure 1b,c). The distal portions of the dorsal and anal fins were blackened posteriorly from the median region of the body. 


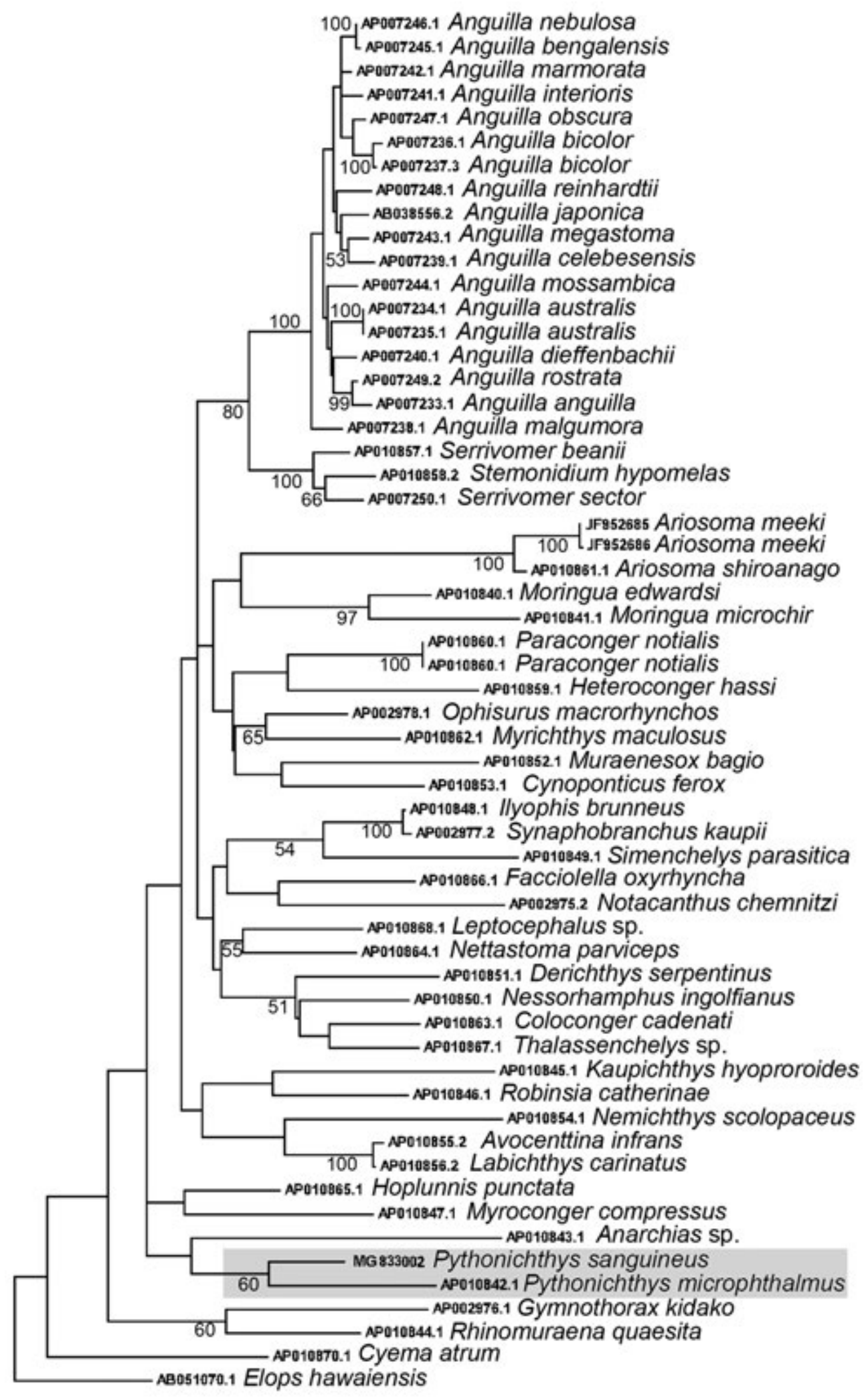

Figure 2. Maximum likelihood tree of the Anguilliformes species analyzed, using GTR+G+l genetic model. Bootstrap values greater than 50 are shown. Species of the genus Pythonichthys are highlighted in gray. 
Table 1. Morphometric and meristic data of three specimens of Pythonichthys sanguineus captured in the vicinity of the Amazon Reef and other geographic areas (Smith, 1989), expressed in millimeters (mm), percent of total length (TL\%) or percent of standard length (SL\%).

\begin{tabular}{|c|c|c|c|c|c|}
\hline & MPEG 35269 & AZUSC 5314 & LBP 26612 & $\begin{array}{c}\text { Amazon Reef } \\
\text { specimens }\end{array}$ & $\begin{array}{c}\text { Other geographic } \\
\text { areas }\end{array}$ \\
\hline & & & & Total length \% & Total length \% \\
\hline Total length & 493 & 650 & 431 & & \\
\hline Preanal length & 173.2 & 223.0 & 142.0 & $33.0-35.1$ & $33-37$ \\
\hline Predorsal length & 61.5 & 71.0 & 49.0 & $10.9-12.5$ & $10-15$ \\
\hline Head length & 59.7 & 70.0 & 48.7 & $10.8-12.1$ & $11-13$ \\
\hline Trunk length & 116.3 & 153.0 & 93.0 & $21.6-23.6$ & \\
\hline Tail length & 317.0 & 427.0 & 295.0 & $64.3-68.5$ & \\
\hline Depth at anus & 20.2 & 29.3 & 16.9 & $3.9-4.5$ & 3 \\
\hline \multirow[t]{2}{*}{ Depth at gill opening } & 20.9 & 26.7 & 18.0 & $4.1-4.2$ & $4-6$ \\
\hline & & & & Standard length \% & Standard length \% \\
\hline Snout length & 9.0 & 9.6 & 7.9 & $13.7-16.2$ & $15-19$ \\
\hline Interorbital & 7.5 & 11.6 & 6.9 & $12.6-16.6$ & $12-15$ \\
\hline Interbranchial & 16.4 & 15.7 & 9.5 & $19.5-27.5$ & $15-25$ \\
\hline Gill opening & 5.1 & 11.3 & 5.0 & $8.5-16.1$ & $9-14$ \\
\hline Jaw length (snout to rictus) & 19.5 & 25.0 & 15.3 & $31.4-35.7$ & $27-36$ \\
\hline Eye diameter & 1.3 & 1.7 & 1.5 & $2.2-3.1$ & $2-5$ \\
\hline Total vertebrae number & 110 & & & & $110-111$ \\
\hline Predorsal vertebrae number & 8 & & & & $8-9$ \\
\hline Preanal vertebrae number & 36 & & & & $36-38$ \\
\hline Caudal vertebrae number & 74 & & & & \\
\hline Vomerine teeth rows & & & 2 & & \\
\hline Maxillary teeth rows & & & 3 & & \\
\hline Mandibular teeth rows & & 3 ant & erior and 4 po & terior & \\
\hline Maxillary teeth length (internal and external rows) & & & same size & & \\
\hline
\end{tabular}

\section{Distribution}

Tropical Western Atlantic Ocean, from Cuba to Brazil (Figure 3). The present study extends the occurrence of the Atlantic mud eels from Suriname to Amapá state in northern Brazil.

\section{Doubtful records from the Brazilian coast}

The occurrence of Pythonichthys sanguineus in Brazilian waters was reported by Miranda-Ribeiro (1919). This record was based on the observation (no specimen collected) of an eel at Trindade Island, off the eastern coast of Brazil, which was identified as Pythonichthys sanguineus based on its intense red coloration. This record was considered doubtful by Simon et al. (2013) and was not accepted by Pinheiro et al. (2015). Hudson Pinheiro (personal information) confirmed that the species does not occur at Trindade Island (Figure 3).

\section{Biology, habitat, depth, and presumed schooling pattern}

There is very little information available for this species, that inhabits muddy substrates of reefs and rocky areas (Smith 2015). Pythonichthys sanguineus has previously been recorded

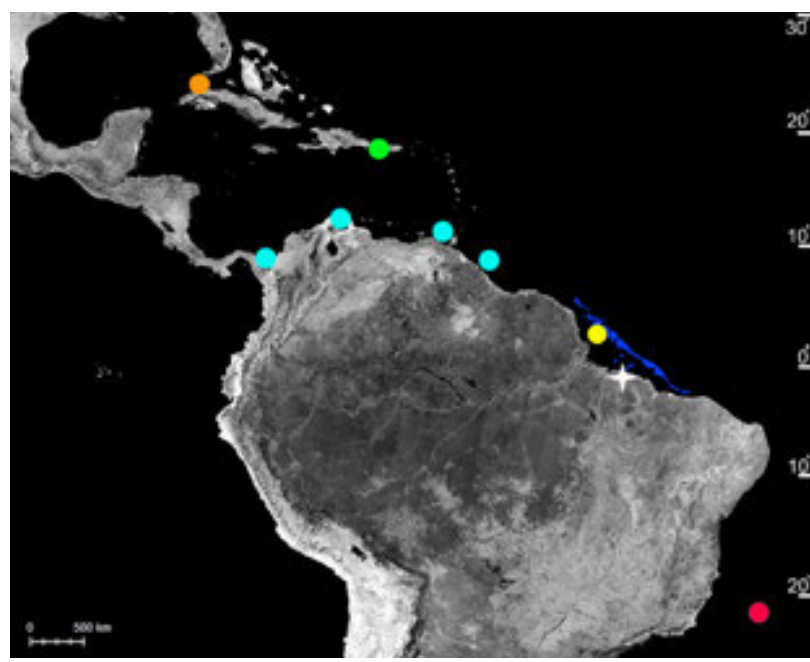

Figure 3. Records of Pythonichthys sanguineus in the western Atlantic. Typelocality of Pythonichthys sanguineus = orange; type-locality of Heterenchelys biaggii = green; non-type specimens = light blue; Brazilian specimens = yellow doubtful records = red; Pirabas Formation (Aguilera et al. 2014) $=$ white star Amazon Reef $=$ dark blue. This figure is in color in the eletronic version. 
at depths of $12-55 \mathrm{~m}$. The cataloged specimens were captured on a gravel bottom, at a depth of between 44 and $50 \mathrm{~m}$, at $2^{\circ} 19^{\prime} 42^{\prime \prime} \mathrm{N}, 48^{\circ} 36^{\prime} 46^{\prime \prime} \mathrm{W}$ to $1^{\circ} 52^{\prime} 45^{\prime \prime} \mathrm{N}, 48^{\circ} 16^{\prime} 32^{\prime \prime} \mathrm{W}$ (Figure 3 ), and the non cataloged specimens were captured on a gravel bottom, at a depth of $70 \mathrm{~m}$, at $2^{\circ} 26^{\prime} 73^{\prime \prime} \mathrm{N}, 48^{\circ} 41^{\prime} 52^{\prime \prime} \mathrm{W}$ (Figure 3), both sites in the vicinity of the Amazon Reef (Moura et al. 2016; Francini-Filho et al. 2018).

\section{Fisheries and conservation}

Otter trawling is practiced worldwide, and is characterized by the largest discarded catches, causing profound impacts on the environment through the destruction of bottom substrates and the elimination of benthic organisms such as coral reefs (Stobutzki et al. 2001). In this context, the capture of the mud eel specimens reported here always ocurred after the end of the closure periods determined by the government to protect shrimp stocks. No other specimens were caught after the beginning of the shrimping season, indicating that the fishing activity may have influence on the occurrence of the species in the fishing zone, as this pattern was observed during the two sampling seasons. This question clearly requires further investigation, given the well-known impact of otter trawling on benthic communities.

\section{DISCUSSION}

Pythonichthys sanguineus is the only species of the genus found in the tropical western Atlantic, and is known from localities in the Caribbean and northern South America, being recognized as part of the typical Greater Caribbean fauna (sensu Robertson and Cramer 2014). The present record of $P$. sanguineus from the vicinity of the Amazon Reef (Moura et al. 2016; Francini-Filho et al. 2018) is relevant to the discussion on the range of the southern limit of the Greater Caribbean fauna, which has been inferred by different authors to reach the region from the Gulf of Paria in Venezuela to Suriname (Petruch 2013) or specific points on the Brazilian coast (Robins 1971), an imprecision that stems from the lack of any prominent physical barriers in the region. In this context, the Amazonian-Orinoco plume, formed by the rearrangements of the hydrographic basins of the Amazon (Shepard et al. 2010) and the Orinoco (Rod 1981), during the middle to late Miocene (7.2 mya) (Figueiredo et al. 2009; Hoorn et al. 2017), has been recognized as an important barrier to the dispersal of coral reef fishes of the Caribbean and Brazil (Bernal and Rocha 2011).

Aguilera et al. (2014) described Pythonichthys pirabasensis based on a fossil from the Aquitanian period of the early Miocene (20.4-23.0 mya), from the Pirabas Formation of Atalaia Beach (municipality of Salinópolis, in the northern Brazilian state of Pará) and concluded that the current interruption of the shallow marine bioprovince, found off the Amazon delta cannot be perceived in the fish fauna of the Pirabas Formation, which is closely related to that of the
Gatunian/proto-Caribbean bioprovince (Petuch 1982, 2013; Landau et al. 2008). The shift of the mouth of the Amazon River, close to its present day location, has terminated the carbonate cycle of the Pirabas Formation, pushing the Pirabas fish fauna northwards, including Pythonichthys and the congrid genus Paraconger Kanazawa 1961, also captured with the Pythonichthys specimens described herein (A.P. Marceniuk, unpublished data).

Our record of Pythonichthys sanguineus indicates that the shift in the location of the Amazon plume may not have displaced the fauna of the Pirabas Formation further north, but only modified the distribution of these lineages from the coastal zone further offshore, to an area where environmental conditions are more similar to those of the Pirabas Formation of the early Miocene (Aquitanian). This area coincides with the recently-discovered coral reefs off the mouth of the Amazon. The fauna associated with the reefs is still poorly-known, but is possibly closely related to those of the Pirabas Formation and the present-day Caribbean (Robertson and Cramer 2014).

\section{ACKNOWLEDGMENTS}

The authors are grateful to Alex Garcia Cavalleiro de Macedo Klautau, coordinator of the Centro de Pesquisa e Gestáo de Recursos Pesqueiros do Litoral Norte (CEPNOR), and Wolmar Benjamin Wosiacki, curator of the fish collection of the Museu Paraense Emílio Goeldi (MPEG), for the opportunity to examine the material collected on the north coast of Brazil. This study was supported by Conselho Nacional de Desenvolvimento Científico e Tecnológico (CNPq) (grants nr. 300462/2016-6 to APM, 306054/2006-0 to $\mathrm{CO}$ ), the Fundação Amazônia Paraense de Amparo à Pesquisa (FAPESPA) (grant nr. ICAAF 017/2016 to APM), and Fundação de Amparo à Pesquisa do Estado de São Paulo (FAPESP) (grant nr. 2016/09204-6 to CO).

\section{REFERENCES}

Aguilera, O. 1998. Los Peces Marinos del Occidente de Venezuela. Acta Biologica Venezuelica, 18: 43-57.

Aguilera, O.; Schwarzhans, W.; Moraes-Santos, H.; Nepomuceno, A. 2014. Before the flood: Miocene otoliths from eastern Amazon Pirabas Formation reveal a Caribbean-type fish fauna. Journal of South American Earth Sciences, 56: 422-446.

Bernal, M.A.; Rocha, L.A. 2011. Acanthurus tractus Poey, 1860, a valid western Atlantic species of surgeonfish (Teleostei, Acanthuridae), distinct from Acanthurus bahianus Castelnau, 1855. Zootaxa, 2905: 63-68.

Blache, J. 1968. Contribution à la connaissance des poisons angulliformes de la cote occidentale d'Afrique, neuvième note: lês Heterenchelyidae. Bulletin de I'I.F.A.N., 30:c1540-1581.

Blache, J. 1977. Leptocephales des poissons anguilliformes dans la zone sud du Golfe de Guinee. ORSTOM, Faune Tropical, 20: 381 . 
Böhlke, J.E. 1956. A small collection of new eels from western Puerto Rico. Notulae Naturae, 289: 1-13.

Cervigón, F. 1991. Los peces marinos de Venezuela. Fundación Científica Los Roques, Caracas, 295p.

Eagderi, S.; Adriaens, D. 2010. Cephalic morphology of Pythonichthys macrurus (Heterenchelyidae: Anguilliformes): specializations for head-first burrowing. Journal of Morphology, 271: 1053-1065.

Faloh-Gandarilla, I.; Gutiérrez, De R.E.; Orozco, M.V.; Cortés, R.; Alfonso, Y.; Lemus, E.; Álvarez, I.L; Pérez, De R.R. 2016. Catálogo de especímenes tipo de peces cubanos (Osteichthyes, clase: Actinopterygii. ordenes: Onguillifomes, Ateleopiformes, Atheriniformes, Aulopiformes, Beloniformes, Beryciformes, Clupeiformes). Parte I. Poeyana Revista Cubana de Zoología, 502: 27-31.

Felsenstein, J. 1985. Confidence limits on phylogenies: an approach using the bootstrap. Evolution, 39: 783-791.

Figueiredo, J.; Hoorn, C.V.P.; Soares, E. 2009. Late Miocene onset of the Amazon River and the Amazon deep-sea fan: evidence from the Foz do Amazonas Basin. Geology, 37: 19-622.

Francini-Filho, R.B.; Asp, N.E.; Siegle, E.; Hocevar, J.; Lowyck, K.; D’Avila, N.; et al. 2018. Perspectives on the Great Amazon Reef: Extension, Biodiversity, and Threats. Frontiers in Marine Science, 5:142.

Hall, M.A. 1996. On bycatches. Reviews in Fish Biology and Fisheries, 6: 319-352.

Hebert, P.D.N.; Cywinska, A.; Ball, S.L.; De Waard, J.R. 2003. Biological identifications through DNA barcodes. Proceedings of the Royal Society of London B, 270: 313-322.

Hoorn, C.; Bogotá, A.G.R.; Romero-Baez, M.; Lammertsma, E.I.D.; Flantua, S.G.A.; Dantas, E.L.; Dino, R.; Do Carmo, D.A.; Chemale, F.Jr. 2017. The Amazon at sea: Onset and stages of the Amazon River from a marine record, with special reference to Neogene plant turnover in the drainage basin. Global Planet Change. http://dx.doi.org/10.1016/j.gloplacha.2017.02.005.

Inoue, J.G.; Miya, M.; Miller, M.J.; Sado, T.; Hanel, R.; Hatooka, K.; Aoyama, J.; Minegishi, Y.; Nishida, M.; Tsukamoto, K. 2010. Deep-ocean origin of the freshwater eels. Biology Letters, 6: 363-366.

Ivanova, N.V.; Fazekas, A.J.; Hebert, P.D.N. 2008. Semi-automated, membrane-based protocol for DNA isolation from plants. Plant Molecular Biology, 26: 186-198.

Kearse, M.; Moir, R.; Wilson, A.; Stones-Havas, S.; Cheung, M.; Sturrock, S.; et al. 2012. Geneious Basic: An integrated and extendable desktop software platform for the organization and analysis of sequence data. Bioinformatics. 28: 1647-1649.

Kimura, M. 1980. A simple method for estimating evolutionary rate of base substitutions through comparative studies of nucleotide sequences. Journal of Molecular Biology, 16: 111-120.

Kumar, S.; Stecher, G.; Tamura, K. 2016. MEGA7: Molecular Evolutionary Genetics Analysis version 7.0 for bigger datasets. Molecular Biology and Evolution, 33: 1870-1874.

Landau, B.; Vermeij, G.; Da Silva, C.M. 2008. Southern Caribbean Neogene palaeobiogeography revisited. New data from the Pliocene of Cubagua, Venezuela. Palaeogeography, Palaeoclimatology, Palaeoecology, 257: 445-461.
Marceniuk, A.P.; Caires, R.; Wosiacki, W.B.; Di Dario, F. 2013. Conhecimento e conservação dos peixes marinhos e estuarinos (Chondrichthyes e Teleostei) da Costa Norte do Brasil. Biota Neotropica, 13: 251-259.

Marceniuk, A.P.; Caires, R.; Rotundo, M.M.; Alcantara, R.A.K.; Wosiacki, W.B. 2017. The icthyofauna (Teleostei) of the Rio Caeté estuary, northeast Pará, Brazil, with a species identification key from northern Brazilian coast. PanamJAS, 12: 31-79.

Miranda-Ribeiro, A. 1919. A fauna vertebrada da ilha da Trindade. Arquivos do Museu Nacional do Rio de Janeiro, 22: 171-193.

Moura, R.L.; Amado-Filho, G.M.; Moraes, F.C.; Brasileiro, P.S.; Salomon, P.S.; Mahiques, M.M.; et al. 2016. An extensive reef system at the Amazon River mouth. Science Advances, 2: e1501252.

Nelson, J.S.; Grande, T.C.; Wilson, M.V. 2016. Fishes of the World. John Wiley \& Sons, Hoboken, USA. 752p.

Ratnasingham, S.; Hebert, P.D.N. 2007. BOLD: The Barcode of Life Data System (www.barcodinglife.org). Molecular Ecology Notes, 7: 355-364.

Regan, C.T. 1912. Description of two new eels from West Africa, belonging to a new genus and family. Annals and Magazine of Natural History, 10: 323-324.

Petuch, E.J. 1982. Geographical heterochrony: contemporaneous coexistence of Neogene and recent molluscan faunas in the Americas. Palaeogeography, Palaeoclimatology, Palaeoecology, 37: 277-312.

Petuch, E.J. 2013. Biodiversity and Biogeography of Western Atlantic Mollusks. CRC Press, Boca Raton, USA. 380p.

Pinheiro, H.T.; Mazzei, E.; Moura, R.L.; Amado-Filho, G.M.; Carvalho-Filho, A.; Braga, A.C.; et al. 2015. Fish biodiversity of the Vitória-Trindade Seamount Chain, Southwestern Atlantic: an updated database. PLoS One, 10: e0118180.

Poey, F. 1868. Monografia de las Morenas cubanas. Repertorio FisicoNatural de la Isla de Cuba, 2: 245-268.

Robertson, D.R.; Cramer, K.L. 2014. Defining and dividing the greater Caribbean: insights from the biogeography of shorefishes. PloS One, 9: e102918.

Robins, C.R. 1971. Distributional patterns of fishes from coastal and shelf waters of the tropical western Atlantic. Symposium on Investigations and Resources of the Caribbean Sea and Adjacent Regions. Papers on Fisheries Resources, FAO, Rome. p.249-255.

Rod, E. 1981. Notes on the shifting course of the ancient Rio Orinoco from late Cretaceous to Oligocene time. GEOS, 26: 54-56.

Rosenblatt, R.H.; Rubinoff, I. 1972. Pythonichthys asodes, a new heterenchelyid eel from the Gulf of Panama. Bulletin of Marine Science, 22: 355-364.

Scharpf, C.; Lazara, K.J. 2017. The ETYFish Project. (http:// www.etyfish.org/wp-content/uploads/2013/10/ETYFish_ Petromyzontiformes.pdf). Accessed on 20 Dec 2017.

Shephard, G.E.; Muller, R.D.; Liu, L.; Gumis, M. 2010. Miocene drainage reversal of the Amazon River driven by plate-mantle interaction. Nature Geoscience, 3: 870-875. 
Simon, T.; Macieira, R.M.; Joyeux, J.C. 2013. The shore fishes of the Trindade-Martin Vaz insular complex: an update. Journal of Fish Biology, 82: 2113-2127.

Smith. D.G. 1989. Family Heterenchelyidae. In: Böhlke, E.B. (Ed.). Fishes of the Western North Atlantic. v. 1. Memoir Sears Foundation for Marine Research. p.48-54.

Smith, D.G. 2002. Family Heterenchelyidae. In: Carpenter, K.E. (Ed.). The living marine resources of the Western Central Atlantic. v.2. FAO Species Identification Guide for Fishery Purposes and American Society of Ichthyologists and Herpetologists Special Publication, Rome, p.601-1374.

Smith, D.G.; Irmak, E.; Ozen, Ö. 2012. A redescription of the eel Panturichthys fowleri (Anguilliformes: Heterenchelyidae), with a synopsis of the Heterenchelyidae. Copeia, 2012: 484-493.

Smith, D.G. 2015. Pythonichthys sanguineus. The IUCN Red List of Threatened Species. e.T195661A2398552. (https://www. iucnredlist.org/species/195661/2398552). Accessed on 11 Dec 2017.

Stobutzki, I.; Miller, M.; Brewer, D. 2001. Sustainability of fishery bycatch: a process for assessing highly diverse and numerous bycatch. Environmental Conservation, 28: 167-181.

Uyeno, T.; Sasaki, T. 1983. Scapanorhynchidae. In: Uyeno, T.; Matsuura, K.; Fujii, E. (Ed.). Fishes trawled off Suriname and French Guiana. Japan Marine Fishery Resource Research Center, Tokyo, p.48.

Ward, R.D.; Zemlak, T.S.; Innes, B.H.; Last, P.R.; Hebert, P.D. 2005. DNA barcoding Australia's fish species. Philosophical Transactions of the Royal Society B, 360: 1847-1857.

RECEIVED: $31 / 07 / 2017$

ACCEPTED: 23/12/2017

ASSOCIATE EDITOR: Izeni Pires Farias

\section{SUPPLEMENTARY MATERIAL}

(only available in the electronic version)

ROTUNDO et al.Record of the rare Caribbean mud eel, Pythonichthys sanguineus (Heterenchelyidae, Anguilliformes), in the region of the Amazon Reef

Appendix S1. GenBank system accession numbers of the sequences of Pythonichthys sanguineus and 57 other anguilliforms used in the present study.

\begin{tabular}{lc}
\hline Species & BOLD Accession \# \\
\hline Anarchias sp. & AP010843.1 \\
Anguilla anguilla & AP007233.1 \\
Anguilla australis & AP007234.1 \\
Anguilla australis & AP007235.1 \\
Anguilla bengalensis & AP007245.1 \\
Anguilla bicolor & AP007236.1 \\
Anguilla bicolor & AP007237.3 \\
Anguilla celebesensis & AP007239.1 \\
Anguilla dieffenbachii & AP007240.1 \\
Anguilla interioris & AP007241.1 \\
\hline
\end{tabular}

Appendix S1. Continued.

\begin{tabular}{|c|c|}
\hline Species & BOLD Accession \# \\
\hline Anguilla japonica & AB038556.2 \\
\hline Anguilla malgumora & AP007238.1 \\
\hline Anguilla marmorata & AP007242.1 \\
\hline Anguilla megastoma & AP007243.1 \\
\hline Anguilla mossambica & AP007244.1 \\
\hline Anguilla nebulosa & AP007246.1 \\
\hline Anguilla obscura & AP007247.1 \\
\hline Anguilla reinhardtii & AP007248.1 \\
\hline Anguilla rostrata & AP007249.2 \\
\hline Ariosoma meeki & ABFJ241-07 \\
\hline Ariosoma meeki & ABFJ242-07 \\
\hline Ariosoma shiroanago & AP010861.1 \\
\hline Avocettina infans & AP010855.2 \\
\hline Coloconger cadenati & AP010863.1 \\
\hline Cyema atrum & AP010870.1 \\
\hline Cynoponticus ferox & AP010853.1 \\
\hline Derichthys serpentinus & AP010851.1 \\
\hline Elops hawaiensis & AB051070.1 \\
\hline Facciolella oxyrhyncha & AP010866.1 \\
\hline Gymnothorax kidako & AP002976.1 \\
\hline Heteroconger hassi & AP010859.1 \\
\hline Hoplunnis punctata & AP010865.1 \\
\hline Ilyophis brunneus & AP010848.1 \\
\hline Kaupichthys hyoproroides & AP010845.1 \\
\hline Labichthys carinatus & AP010856.2 \\
\hline Leptocephalus sp. & AP010868.1 \\
\hline Moringua edwardsi & AP010840.1 \\
\hline Moringua microchir & AP010841.1 \\
\hline Muraenesox bagio & AP010852.1 \\
\hline Myrichthys maculosus & AP010862.1 \\
\hline Myroconger compressus & AP010847.1 \\
\hline Nemichthys scolopaceus & AP010854.1 \\
\hline Nessorhamphus ingolfianus & AP010850.1 \\
\hline Nettastoma parviceps & AP010864.1 \\
\hline Notacanthus chemnitzi & AP002975.2 \\
\hline Ophichthus altipennis & ABFJ240-07 \\
\hline Ophisurus macrorhynchos & AP002978.1 \\
\hline Paraconger notialis & AP010860.1 \\
\hline Pythonichthys microphthalmus & AP010842.1 \\
\hline Pythonichthys sanguineus & MG833002 \\
\hline Rhinomuraena quaesita & AP010844.1 \\
\hline Robinsia catherinae & AP010846.1 \\
\hline Serrivomer beanii & AP010857.1 \\
\hline Serrivomer sector & AP007250.1 \\
\hline Simenchelys parasitica & AP010849.1 \\
\hline Stemonidium hypomelas & AP010858.2 \\
\hline Synaphobranchus kaupii & AP002977.2 \\
\hline Thalassenchelys sp. & AP010867.1 \\
\hline
\end{tabular}

